\title{
Effects of Nodes on the Properties of Laminated Bamboo Lumber
}

\author{
I.M. Sulastiningsih, Surdiding Ruhendi, Muh. Yusram Massijaya, \\ I Wayan Darmawan, and Adi Santoso
}

\begin{abstract}
The objective of this study was to determine the effects of node on the properties of laminated bamboo lumber (LBL) glued with water based polymer-isocyanate adhesive. Bamboo strips for LBL fabrication were prepared from andong bamboo (Gigantochloa pseudoarundinacea) collected from private gardens in West Java. Each bamboo strip has dimension of 40 $\mathrm{cm} \times 2 \mathrm{~cm} \times 0.5 \mathrm{~cm}$. The bamboo strips were assigned into 3 groups by the node positions: without node, with node position of $10 \mathrm{~cm}$ from one end of the bamboo strip, and with node position in the centre of the bamboo strip. Prior LBL fabrication, the bamboo strips were treated by cold soaking in $7 \%$ boron solution for $2 \mathrm{~h}$. The laboratory scale 3-layer laminated bamboo lumbers were manufactured with 5 different layer compositions: all layers made of bamboo strips without node, inner layer made of bamboo strips with nodes at $10 \mathrm{~cm}$ from one end of the strip, inner layer made of bamboo strips with nodes at the centre of the strip, all layers made of bamboo strips with nodes at $10 \mathrm{~cm}$ from one end of the strip, and all layers made of bamboo strips with nodes at the centre of the strip. The glue spread and cold pressing time applied were $250 \mathrm{~g} / \mathrm{m}^{2}$ and $1 \mathrm{~h}$, respectively.

The results showed that the average density, moisture content, thickness swelling, bending strength and compression strength of laminated bamboo lumbers were $0.74 \mathrm{~g} / \mathrm{cm}^{3}, 11.3 \%, 2.9 \%, 1090 \mathrm{~kg} / \mathrm{cm}^{2}$, and $560 \mathrm{~kg} / \mathrm{cm}^{2}$, respectively. No delamination occurred in all samples, indicating high bonding quality. The average bonding strength (dry test) of laminated bamboo lumbers was $70.3 \mathrm{~kg} / \mathrm{cm}^{2}$. Several properties of laminated bamboo lumber were not significantly affected by the present of nodes in the bamboo strips except the thickness swelling and compression strength.
\end{abstract}

Keywords: Laminated bamboo lumber, node, isocyanate, physical and mechanical properties.

\section{Introduction}

The demand of wood as furniture and building materials always increase in line with the increase in the number of population. The total population of Indonesia in 2000 was 205,132 millions while in 2010 was 237,556 millions with the annual growth rate of $1.49 \%$ (BPS 2010). According to Supriana et al. (2003), the need for houses in Indonesia was about 2.9 million units per year and every unit of house consumes about $2.97 \mathrm{~m}^{3}$ of wood on average. This means that approximately 8.613 million $\mathrm{m}^{3}$ of sawn timber is needed annually for housing construction. Since the wood supply for housing industry has been decreasing considerably, the search for substitutes is an urgent concern.

Bamboo has the potential to be an alternative to housing materials due to its ability to grow fast in various soils with desirable properties. Although there is a long history in the use of bamboo as construction materials, furniture, household utensils and handicrafts in Indonesian villages, the shape and dimension appear to limit the usage of bamboo. Due to its circular and hollow shape, bamboo must be converted into flat and relatively thick material as wood substitutes. It is fortunately possible to produce timber-like-material with desired dimension from bamboo strips, so-called laminated bamboo lumber (LBL) by the aid of appropriate adhesives. LBL is a lumber-like product in dimension, consisting of several layers of bamboo sheets bonded together with the grain in parallel direction, and may be formed into planks or beams. This paper describes the results of an experiment to determine the effects of nodes on the properties of laminated bamboo lumber (LBL).

Previous studies related to development of LBL have been carried out by several investigators with the differences in processing technique such as the bamboo species used, type of lamina element, number of layer, laminae direction, pre-treatment of bamboo strips, adhesive type, adhesive spread rate and pressing condition in the LBL manufacture. Studies on the properties of LBL made from bamboo zephyr mats of betung bamboo (Dendrocalamus asper) and andong bamboo (Gigantochloa pseudoarundinacea) glued with urea formaldehyde and cold pressing applied for $20 \mathrm{~h}$ were carried out by Sulastiningsih et al. (1996,1998), whereas Nugroho and Ando (2001) studied the fundamental properties of LBL made from bamboo zephyr mats of moso bamboo (Phyllostachys pubescens) glued with resorcinol-based adhesive and cold pressing applied for $12 \mathrm{~h}$. Studies on the development of LBL made from bamboo strips as a potential wood substitute have been carried out by previous investigators (Lee and Liu 2003, Sulastiningsih et al. 2005, Guo 2007, Rittironk and Elnieiri 2008, Correal and Lopez 2008, Sulasiningsih and Nurwati 2009, Correal and Ramirez 2010, Mahdavi et al. 2011, Sulastiningsih et al. 2012). Those studies did not take into account the effects of node position in the bamboo strips on the properties of LBL produced. 


\section{Materials and Methods}

Andong bamboo (Gigantochloa pseudoarundinacea) was used in the experiment because this bamboo species is widely planted in West Java. Ten mature culms of $G$. pseudoarundinacea were collected from private gardens in Bogor, West Java. The culms used in the experiment were obtained by taking out the first segment at about $60 \mathrm{~cm}$ in length from the bottom. The remaining culms (only the bottom and middle parts) measuring about $8 \mathrm{~m}$ in length were cross cut into segments. Each segment was $90 \mathrm{~cm}$ in length and generally had two internodes.

\section{Preparation of Bamboo Strips}

To produce bamboo strips, each bamboo segment (90 $\mathrm{cm}$ in length) was manually fed into a bamboo splitter machine. Six to seven strips were obtained from each segment, each about $2 \mathrm{~cm}$ wide. Only straight bamboo strips were used for this study. After scraping out the inner and outer layers, the selected strips were then planed and stacked for air drying at room temperature for one week. Then, the bamboo strips were immersed in $7 \%$ boron solution for two hours and after which they were sun-dried to about $12 \%$ moisture content. The bamboo strips were then cross cut into $40 \mathrm{~cm}$ length and assigned into 3 groups by the position of node: without node, with the node position of $10 \mathrm{~cm}$ from one end of bamboo strip, and with the node position in the centre of bamboo strip.

\section{Producing Bamboo Sheet}

Each bamboo sheet comprised of eight bamboo strips. The bamboo strips were assembled side-by-side and edgeglued using water based polymer-isocyanate adhesive with the resin emultion: isocyanate crosslinker ratio was 100:15 by weight. The glue mix of $250 \mathrm{~g} / \mathrm{m}^{2}$ for a single glue line was then hand-spread on each side surface of bamboo strips using a metal spatula. The assemblies were cold-pressed for one hour using a wooden clamp.

\section{Producing Laminated Bamboo Lumbers (LBLs)}

LBLs were produced by assembling three layers of bamboo sheet (each bamboo sheet consisted of 8 bamboo strips) with the grain in parallel direction. The laboratory scale 3-layer laminated bamboo lumbers were manufactured with 5 different layer compositions : all layers made of bamboo strips without node $\left(P_{1}\right)$, inner layer made of bamboo strips with nodes at $10 \mathrm{~cm}$ from one end of the bamboo strip $\left(P_{2}\right)$, inner layer made of bamboo strips with nodes at the centre of the strip $\left(P_{3}\right)$, all layers made of bamboo strips with nodes at $10 \mathrm{~cm}$ from one end $\left(\mathrm{P}_{4}\right)$, and all layers made of bamboo strips with nodes at the centre of the strip $\left(P_{5}\right)$. The $L B L$ was manufactured using isocyanate adhesive. The assemblies were cold-pressed using a wooden clamp for one hour and the glue spread applied was $250 \mathrm{~g} / \mathrm{m}^{2}$. Three replications for each treatment of LBL were prepared. The LBLs produced were conditioned for two weeks before testing.

\section{Testing}

The laminated bamboo lumbers were cut into desired specimen dimensions and measured for density, moisture content, thickness swelling, width expansion, modulus of rupture (MOR), modulus of elasticity (MOE), compression strength and bonding strength. The tests were performed using the American Standard ASTM D 1037-93 (ASTM 1995) with some modifications and Japanese Standard for Glued Laminated Timber (JPIC 2003) for evaluating properties of LBLs. A completely randomized design was used in the experiment with the position of nodes in the bamboo sheet as the treatment factor. Three replications were prepared for each treatment.

\section{Results and Discussion}

The mean values of physical and mechanical properties of laminated bamboo lumbers (LBLs) and the results of analysis of variance (ANOVA) are presented in Table 1. The moisture content of LBLs varied from 11.1 to $11.6 \%$ with an average of $11.3 \%$. The moisture content of LBL was not affected by the present of nodes in the bamboo strips.

The density of LBLs produced varied from 0.73 to 0.75 $\mathrm{g} / \mathrm{cm}^{3}$ with an average of $0.74 \mathrm{~g} / \mathrm{cm}^{3}$. These values were higher than the original air dry density of bamboo raw material. The average air dry density of $G$. pseudoarundinacea strips in this study was $0.72 \mathrm{~g} / \mathrm{cm}^{3}$. Possible reasons that contributed to the higher value are the use of adhesive and the pressure applied during laminated bamboo lumbers manufacture, which produced a denser product. According to Dransfield and Widjaya (1995), the specific gravity of Gigantochloa pseudoarundinacea is $0.5 \sim 0.7$ (internodes) and $0.6 \sim 0.8$ (parts with nodes). ANOVA showed that the density of LBLs was not affected by the present of nodes in the bamboo strips.

Thickness swelling of LBLs varied from 1.5 to $3.9 \%$ with an average of $2.9 \%$. A previous study by Nugroho and Ando (2001) showed that the average thickness swelling of four-layer laminated bamboo lumber made from moso bamboo (bamboo zephyr mats) glued with resorcinol-based adhesive was $12.13 \%$. Other study was carried out by Lee and Liu (2003) on selected physical properties of commercial bamboo flooring and the result showed that the thickness swelling of laboratory made three-layer laminated bamboo lumber and natural bamboo flooring made from moso bamboo strips were 1.0 and $0.7 \%$ respectively. Thickness swelling of LBL made from andong bamboo strips glued with tannin resorcinol formaldehyde with layer composition in combination with acacia and pine wood varied from 0.8 to $3.3 \%$ (Sulastiningsih et al. 2005). Parallel and crossed-laminated bamboo panel made from 
Dendrocalamus yunnanicus had thickness swellings of 3.5 and $3.6 \%$ respectively (Guo 2007). From this information, it was found that LBL made from bamboo strips had better dimensional stability than LBL made from bamboo zephyr mats. ANOVA showed that the thickness swelling of LBL was significantly affected by the present of nodes in the bamboo strips. The present of nodes reduced thickness swelling of LBL. The possible reason is the structure especially vascular cells of the node section of the bamboo culm is more complicated than the internode's section (Shao et al. 2010) resulted in denser and harder materials and this condition will hinder water to enter the LBL.

The width expansion (WE) of LBL varied from 1.8 to $2.7 \%$ with an average of $2.3 \%$. This finding is in agreement with the previous study which reported that the width expansion of $L B L$ made from andong bamboo strips glued with urea formaldehyde varied from 2.04 to $2.70 \%$ with an average of $2.38 \%$ (Sulastiningsih and Santoso 2012). ANOVA showed that the width expansion of LBLs was not affected by the present of nodes in the bamboo strips.

The MOR of laminated bamboo lumbers varied from 971 to $1198 \mathrm{~kg} / \mathrm{cm}^{2}$ (Table 1). The data on MOR of LBLs were subjected to analysis of variance (ANOVA) and the results showed that the MOR of LBLs was not affected by the present of nodes in the bamboo strips. Compared to Indonesian wood strength class (Seng 1964), based on MOR value, the three-layer LBLs produced had strength values similar to wood strength class II $\left(725 \sim 1100 \mathrm{~kg} / \mathrm{cm}^{2}\right)$ to I ( > $1100 \mathrm{~kg} \mathrm{~cm}^{-2}$ ). MOR of a four-layer laminated bamboo lumber made from moso bamboo (bamboo zephyr mats) glued with resorcinol-based adhesive varied from 639 to $707 \mathrm{~kg} \mathrm{~cm}^{-2}$ (Nugroho and Ando 2001). The four-layer laminated bamboo lumber had strength values similar to Indonesian wood strength class III (500 $\left.725 \mathrm{~kg} / \mathrm{cm}^{2}\right)$. Guo (2007) reported that MOR of parallel and crossed laminated panels made from D. yunnanicus were 210 and $195 \mathrm{MPa}$ respectively, while that panels made from Heterocycla pubescens were 175 and $136 \mathrm{MPa}$ respectively. Those strength values are similar to Indonesian wood strength class I (>1100 kgcm 2$)$. Correal and Lopez (2008) reported that the MOR of Colombian glued laminated bamboo (Guadua angustifolia Kunt), which used polyvinyl acetate (PVA) as adhesive was $81.9 \mathrm{MPa}$ or $835 \mathrm{~kg} / \mathrm{cm}^{2}$ (similar to Indonesian wood strength class II). Other study showed that three-layer and five-layer LBLs made from bamboo zephyr mats of $D$. asper glued with urea formaldehyde were 1031 and $962 \mathrm{~kg} / \mathrm{cm}^{2}$ respectively which were compal
Indonesian wood strength class II (Sulastiningsih et al. 1996). MOR of a three-layer LBL made from bamboo strips of $G$. pseudoarundinacea glued with tannin recorsinol formaldehyde was $1241 \mathrm{~kg} / \mathrm{cm}^{2}$ (Sulastiningsih et al. 2005), whereas the MOR of that glued with urea formaldehyde was $1236 \mathrm{~kg} / \mathrm{cm}^{2}$ (Sulastiningsih and Santoso 2012). Those MOR values were similar to Indonesian wood strength class I (>1100 kg/cm²). Based on this information, it was found that in general the LBL made from bamboo strips had MOR value that is higher than that of LBL made from bamboo zephyr mats.

Syafii (1984) in Suryokusumo and Nugroho (1994) reported that the MOR of andong bamboo culm ( $G$. pseudoarundinacea) was $1356 \mathrm{~kg} / \mathrm{cm}^{2}$, while Dransfield and Widjaya (1995) reported that the MOR of andong bamboo culm varied from 1745 to $2112 \mathrm{~kg} / \mathrm{cm}^{2}$. Other investigator (Idris et al. 1994) reported that the MOR of $G$. pseudoarundinacea was $1032.6 \mathrm{~kg} / \mathrm{cm}^{2}$ (parts with nodes) and $1835.6 \mathrm{~kg} / \mathrm{cm}^{2}$ (internodes). It can be seen that the MOR of laminated bamboo lumber is lower than the MOR of the original bamboo. This was due to the fact that in bamboo sheets of LBL specimen, there are many small splits which occurred from some imperfect joints among strips and, thus, reduced the strength of $\mathrm{LBL}$. Conversely, the specimen used in determining MOR of the original bamboo strip was the small clear specimen.

MOE of laminated bamboo lumbers varied from 163,667 to $176,257 \mathrm{~kg} / \mathrm{cm}^{2}$ with an average of 170,563 $\mathrm{kg} / \mathrm{cm}^{2}$. MOE values of LBL in this study had similar trend with that of the MOR values of LBL (Table 1). The result of analysis of variance showed that the present of nodes in the bamboo strips did not affect the MOE value of $L B L$. Sulastiningsih et al (1998) reported that the MOE of laminated bamboo lumber made from bamboo zephyr mats of $G$. pseudoarundinacea glued with urea formaldehyde varied from 116,070 to $202,310 \mathrm{~kg} / \mathrm{cm}^{2}$ with an average of $146,960 \mathrm{~kg} / \mathrm{cm}^{2}$, whereas the MOE of LBL made from bamboo strips of $G$. pseudoarundinacea glued with tannin recorsinol formaldehyde was 133,615 $\mathrm{kg} / \mathrm{cm}^{2}$ (Sulastiningsih et al. 2005). Syafii (1984) in Suryokusumo and Nugroho (1994) reported that the MOE of $G$. pseudoarundinacea was $98,294 \mathrm{~kg} / \mathrm{cm}^{2}$ while Idris et. al. (1994) reported that the MOE values of $G$. pseudoarundinacea were $96,616 \mathrm{~kg} / \mathrm{cm}^{2}$ (part with nodes) and $121,395 \mathrm{~kg} / \mathrm{cm}^{2}$ (internodes). It can be seen that the MOE of laminated bamboo lumber is higher than the MOE of the original bamboo. 
Table 1. Physical and mechanical properties of LBLs and the results of ANOVA

\begin{tabular}{|c|c|c|c|c|c|c|}
\hline \multirow[t]{2}{*}{ Properties } & \multicolumn{5}{|c|}{ Position of nodes } & \multirow[b]{2}{*}{ ANOVA results } \\
\hline & $\mathrm{P}_{1}$ & $\mathrm{P}_{2}$ & $\mathrm{P}_{3}$ & $\mathrm{P}_{4}$ & $P_{5}$ & \\
\hline \multirow[t]{2}{*}{$\mathrm{MC}(\%)$} & 11.2 & 11.6 & 11.1 & 11.3 & 11.5 & ns \\
\hline & $(0.08)$ & $(0.19)$ & $(0.68)$ & $(0.33)$ & $(0.40)$ & \\
\hline \multirow[t]{2}{*}{ Density $\left(\mathrm{g} / \mathrm{cm}^{3}\right)$} & 0.74 & 0.73 & 0.75 & 0.75 & 0.74 & ns \\
\hline & $(0.03)$ & $(0.03)$ & $(0.03)$ & $(0.03)$ & $(0.02)$ & \\
\hline \multirow[t]{2}{*}{ TS (\%) } & 3.1 & 3.9 & 3.1 & 2.6 & 1.5 & ** \\
\hline & $(0.37)$ & $(0.07)$ & $(0.38)$ & $(0.71)$ & $(0.12)$ & \\
\hline \multirow[t]{2}{*}{ WE (\%) } & 2.2 & 2.7 & 2.3 & 2.4 & 1.8 & ns \\
\hline & $(0.59)$ & $(0.60)$ & $(0.16)$ & $(0.03)$ & $(0.23)$ & \\
\hline \multirow[t]{2}{*}{$\operatorname{MOR}\left(\mathrm{kg} / \mathrm{cm}^{2}\right)$} & 1159 & 1039 & 1198 & 971 & 1085 & ns \\
\hline & (151) & (139) & (167) & (184) & (69) & \\
\hline MOE & 175.3 & 171.4 & 176.3 & 163.7 & 166.2 & ns \\
\hline$\left(\times 10^{3} \mathrm{~kg} / \mathrm{cm}^{2}\right)$ & (20.2) & (20.1) & $(6.8)$ & (16.7) & $(9.6)$ & \\
\hline \multirow[t]{2}{*}{$\mathrm{CS}\left(\mathrm{kg} / \mathrm{cm}^{2}\right)$} & 549.8 & 629.4 & 571.2 & 533.1 & 518.6 & * \\
\hline & (29) & (72) & (13) & (11) & (77) & \\
\hline \multirow[t]{2}{*}{$\mathrm{BS}\left(\mathrm{kg} / \mathrm{cm}^{2}\right)$} & 71.1 & 64.4 & 72.3 & 72.7 & 71.2 & ns \\
\hline & (2.5) & $(3.8)$ & (2.9) & (8.2) & (6.7) & \\
\hline Delamination,\% & 0 & 0 & 0 & 0 & 0 & \\
\hline
\end{tabular}

Each value was the average of three specimens except for bonding strength which had six specimens. Numbers in parentheses represent one standard deviation; MC, moisture content; TS, thickness swelling; WE, width expansion; MOR, modulus of rupture; MOE, modulus of elasticity; CS, compression strength; BS, bonding strength; ns : not significant; * : significant ; **, highly significant.

The compression strength of LBL varied from 518.6 to $629.4 \mathrm{~kg} / \mathrm{cm}^{2}$ with an average of $560.4 \mathrm{~kg} / \mathrm{cm}^{2}$. Compared to Indonesian wood strength class (Seng 1964), based on compression strength value, the three-layer LBLs produced had strength values similar to wood strength class II (425 $650 \mathrm{~kg} / \mathrm{cm}^{2}$ ). The previous study (Sulastiningsih and Santoso 2012) reported that the compression strength of LBL made from andong bamboo strips glued with urea formaldehyde varied from 522 to $580 \mathrm{~kg} / \mathrm{cm}^{2}$ with an average of $562 \mathrm{~kg} / \mathrm{cm}^{2}$. Correal and Lopez (2008) reported that the compression strength of Colombian glued laminated bamboo (Guadua angustifolia Kunt) which used polyvinyl acetate (PVA) as adhesive was $47.6 \mathrm{MPa}$ or $485 \mathrm{~kg} / \mathrm{cm}^{2}$ (similar to Indonesian wood strength class II). ANOVA (Table 1) showed that the compression strength of LBLs was significantly affected by the present of nodes in the bamboo strips. The present of nodes reduced the compression strength of LBL. This was due to the structure, especially vascular cells of the node section of the bamboo culm which is more complicated than the internode section (Shao et al. 2010), resulted in denser and harder materials. This condition will bring some difficulties in manufacturing process of LBL especially in joining or gluing process of bamboo strips and assembling several bamboo sheets to produce LBL which needs higher pressure to apply. Consequently, the intimate contact among bamboo strips or bamboo sheets does not achieve the maximum condition.

The delamination test and glue shear strength test were carried out to determine the bonding quality of LBLs glued with isocyanate adhesive. The result of the delamination test showed that there was no delamination in all samples and, therefore, the bonding quality of the LBLs was considered acceptable. The glue shear strength test showed that the bonding strength (dry test) of LBL produced varied from 64.4 to $72.7 \mathrm{~kg} / \mathrm{cm}^{2}$ with an average of $70.3 \mathrm{~kg} / \mathrm{cm}^{2}$. Those values surpassed the minimum requirement of Japanese Standard for Glued Laminated Timber (JPIC 2003). Previous study by Correal and Lopez (2008) showed that the bonding strength of Colombian glued laminated bamboo (Guadua angustifolia Kunt) which used polyvinyl acetate (PVA) as adhesive was $7.92 \mathrm{MPa}$ $\left(80.78 \mathrm{~kg} / \mathrm{cm}^{2}\right)$. Ashaari et al. (2004) reported that the bonding quality of $G$. scortechinii laminates had superior glue bond quality than $D$. asper. Other study (Hanim et al. 2010) reported that preservative treatments on bamboo 
strips of G. scortechinii significantly affect shear strength and wood failure of the laminates. Shear strength and wood failure of the laminated bamboo were significantly reduced especially in the wet condition where the range is $0 \mathrm{~N} / \mathrm{mm}^{2}$ (WBP-treated) to $0.65 \mathrm{~N} / \mathrm{mm}^{2}$ (boiled-treated) when compared to untreated bamboo laminates $(0.79$ $\mathrm{N} / \mathrm{mm}^{2}$ ). On the other hand, in dry condition test, the glue bond strength of the laminated bamboo ranged from 0.64 $\mathrm{N} / \mathrm{mm}^{2}$ (WBP-treated) to $2.04 \mathrm{~N} / \mathrm{mm}^{2}$ (borax-treated).

\section{Conclusions}

Several properties of laminated bamboo lumber were not affected by the present of nodes in the bamboo strips except the thickness swelling and compression strength. Based on the Indonesian wood strength classification, the three-layer laminated bamboo lumbers glued with isocyanate adhesive had comparable strength to the wood strength class II.

\section{References}

American Society for Testing and Materials (ASTM).1995. Standard Test Methods for Evaluating Properties of Wood-Based Fiber and Particle Panel Materials. Annual Book of ASTM Standard. ASTM D 1037-93. Philadelphia.

Ashaari, Z.; R. Hanim; P.M. Tahir; N. Nizam. 2004. Effects of Peroxide and Oxalic Acid Bleaching on the Colour and Gluing Properties of Some Tropical Bamboos. Journal of Biological Science 4(2): 90-94

Badan Pusat Statistik. (BPS). 2010. Statistik Indonesia 2010. Katalog BPS: 1101001. Badan Pusat Statistik. Jakarta.

Correal, J.; L. Lopez. 2008. Mechanical Properties of Colombian Glued Laminated Bamboo in Xiao et al. (Editors). Modern Bamboo Structures. Proceedings of First International Conference on Modern Bamboo Structures (ICBS-2007), Changsa, China, 28-30 October 2007. Pp $121-127$

Correal, J.; F. Ramirez. 2010. Adhesive Bond Performance in Glue Line Shear and Bending for Glued Laminated Guadua Bamboo. Journal of Tropical Forest Science 22(4): 433-439.

Dransfield, S.; E.A. Widjaya. 1995. Plant Resources of South East Asia No 7; Bamboos. Backhuys Publishers. Leiden.

Guo, Z.W.W. 2007. Laminated Panel Manufacture of Two Kinds of Bamboo for Architecture Material and Property Comparison. http://www.inbar.int/publication/pubdownload.asp. Accessed on 28 June 2007.

Hanim, A.R.; A. Zaidon; F. Abood; U.M.K. Anwar. 2010. Adhesion and Bonding Characteristics of PreservativeTreated Bamboo (Gigantochloa scortechinii)
Laminates. Journal of Applied Sciences 10(14): 1435 1441.

Idris, A.A.; A. Firmanti; Purwito. 1994. Penelitian Bambu Untuk Bahan Bangunan. Strategi Penelitian Bambu Indonesia. Yayasan Bambu Lingkungan Lestari. Bogor: 73-81.

Japan Plywood Inspection Corporation (JPIC). 2003. Japanese Agricultural Standard for Glued Laminated Timber. JAS, MAFF, Notification No. 234. Japan Plywood Inspection Corporation. Tokyo.

Lee, A.W.C.; Y. Liu. 2003. Selected Physical Properties of Commercial Bamboo Flooring. Forest Products Journal 53(6): 23-26.

Mahdavi, M.; P.L. Clouston; S.R. Arwade. 2011. Development of Laminated Bamboo Lumber: Review of Processing, Performance, and Economical Considerations. Journal of Materials in Civil Engineering 23(7):1036-1042.

Nugroho, N.; N. Ando. 2001. Development of Structural Composite Products made from Bamboo II: Fundamental Properties of Laminated Bamboo Board. Journal of Wood Science 47(3): 237-242.

Rittironk, S.; M. Elnieiri. 2008. Investigating Laminated Bamboo Lumber as an Alternate to Wood Lumber in Residential Construction in the United States. Proceedings of First International Conference on Modern Bamboo Structures (ICBS-2007), Changsa, China, 28-30 October 2007. Pp 83-96.

Seng, O.D. 1964. Berat Jenis dari Jenis-Jenis Kayu Indonesia dan Pengertian Beratnya Kayu untuk Keperluan Praktek. Pengumuman LPHH No 1. Bogor.

Shao, Z. P.; L.. Zhou; Y.M. Wu; C. Arnaud. 2010. Differences in Structure and Strength between Internode and Node Sections of Moso Bamboo. Journal of Tropical Forest Science 22(2): 133-138.

Sulastiningsih, I.M.; Nurwati; P. Sutigno. 1996. Pengaruh Jumlah Lapisan terhadap Sifat Bambu Lamina. Buletin Penelitian Hasil Hutan 14(9): 366-373. Pusat Penelitian dan Pengembangan Hasil Hutan \& Sosial Ekonomi Kehutanan. Bogor. Indonesia.

Sulastiningsih, I.M.; A. Santoso; T. Yuwono. 1998. Effect of Position Along the Culm and Number of Preservative Brushing on Physical and Mechanical Properties of Laminated Bamboo. Proceedings Pacific Rim BioBased Composites Symposium. November 2-5, 1998, Bogor, Indonesia :106 - 113. Faculty of Forestry, Bogor Agricultural University. Bogor.

Sulastiningsih, I.M.; Nurwati; A. Santoso. 2005. Pengaruh Lapisan Kayu terhadap Sifat Bambu Lamina. Jurnal Penelitian Hasil Hutan 23(1): 15-22. Pusat Penelitian dan Pengembangan Hasil Hutan. Bogor. Indonesia.

Sulastiningsih, I.M.; Nurwati. 2009. Physical and Mechanical Properties of Laminated Bamboo Board. Journal of Tropical Forest Science 21(3): 246-251.

Sulastiningsih, I.M.; A. Santoso. 2012. Pengaruh Jenis Bambu, Waktu Kempa dan Perlakuan Pendahuluan 
Bilah Bambu terhadap Sifat Papan Bambu Lamina. Jurnal Penelitian Hasil Hutan 30(3): 198-206. Pusat Penelitian dan Pengembangan Keteknikan Kehutanan dan Pengolahan Hasil Hutan. Bogor. Indonesia.

Supriana, N.; S. Abdurrohim; Barly; Jasni; Djarwanto; J. Malik; M. Muslich; D. Martono; P. Permadi. 2003. Kajian Peran Pengawetan Kayu Perumahan dan Gedung dalam rangka Pengelolaan Hutan Lestari. Laporan Hasil Penelitian. Pusat Penelitian dan Pengembangan Teknologi Hasil Hutan. Bogor. Tidak terbit.

Suryokusumo, S.; N. Nugroho. 1994. Pemanfaatan Bambu Sebagai Bahan Bangunan. Strategi Penelitian Bambu Indonesia. Yayasan Bambu Lingkungan Lestari. Bogor : 82-87.
I.M. Sulastiningsih and Adi Santoso

The Center for Research and Development on Forest

Engineering and Forest Products Processing,

Bogor, INDONESIA

Address : Jl. Gunung Batu No. 5, Bogor 16610, Indonesia

Tel : +62- 251- 8633378

Fax : :62- 251- 8633413

E-mail : tsulastiningsih@yahoo.co.id; asanto10@yahoo.com

Surdiding Ruhendi, Muh. Yusram Massijaya, and I Wayan Darmawan

Faculty of Forestry, Bogor Agricultural University, INDONESIA

Address :

Tel : +62- 251- 8422982/8621285

Fax : +62-251- 8621285

E-mail : sdidingr@gmail.com; mymassijaya@yahoo.co.id; wayandar@indo.net.id 